\title{
Effects of recent sexual experience and melatonin treatment of rams on plasma testosterone concentration, sexual behaviour and ability to induce ovulation in seasonally anoestrous ewes
}

\author{
H. J. D. Rosa*, D. T. Juniper and M. J. Bryant \\ Department of Agriculture, University of Reading, Whiteknights, PO Box 236, Reading RG6 6AT, UK
}

\begin{abstract}
The aim of this study was to determine whether advancing the seasonal changes associated with rams by treatment with exogenous melatonin and allowing the rams previous sexual experience would increase the proportion of anoestrous ewes ovulating in early July. North Country Mule ewes $(n=225)$ were grouped by live body weight and body condition score and allocated randomly to the following treatments: (i) isolated from rams (control; $\mathrm{n}=25$ ); (ii) introduced to rams (treatment 2); (iii) introduced to rams that had mated with ewes during the previous 2 days (treatment 3 ); (iv) introduced to rams implanted with melatonin (treatment 4); and (v) introduced to rams that were implanted with melatonin and had mated with ewes during the previous 2 days (treatment 5). Treatments $2-5$ were replicated $(2 \times 25$ ewes) and two rams were introduced to each replicate group. Introductions began on 4 July and were completed by 11 July. The rams were withdrawn from the ewes after 8 days. Melatonin was administered as a subcutaneous implant (Regulin ${ }^{\circledR}$ ) on 22 May and again on 20 June. Blood samples were taken from all rams to determine plasma melatonin and testosterone concentrations (19 samples in $6 \mathrm{~h}$ ). The behaviour of the sheep was videotaped continuously during the first $3 \mathrm{~h}$ after the ram was introduced. Ovulation was detected by an increase in plasma progesterone concentrations from $<0.5 \mathrm{ng} \mathrm{ml}^{-1}$ to $>0.5 \mathrm{ng} \mathrm{ml}^{-1}$. Mean \pm SE plasma melatonin concentrations were $649.7 \pm 281.4$ and $18.3 \pm 2.4 \mathrm{pg} \mathrm{ml}^{-1}$ in rams with and without melatonin implants, respectively $(P<0.001)$. Melatonin implants also increased plasma testosterone concentrations from $4.30 \pm 1.88$ to $10.10 \pm 1.10 \mathrm{ng} \mathrm{ml}^{-1}(P<0.01)$, the libido of the rams and the proportion of ewes that ovulated in response to the rams ( 43 and $56 \%$ (treatments 4 and 5) versus $24 \%$ (treatments 2 and 3)). In conclusion, implanting rams with melatonin before introducing them to seasonally anoestrous ewes increases the proportion of ewes that ovulate in response to introduction of a ram, but previous sexual experience of rams appears to have little or no effect.
\end{abstract}

\section{Introduction}

It is now well recognized that the response of seasonally anoestrous ewes to introduction of rams is dependent on pheromonal and sexual behavioural stimuli emanating from the rams. The site of pheromone synthesis, although not yet demonstrated, appears to be the sudoriferous glands (Knight and Lynch, 1980); fleece from any part of a ram's body and ethanol or methylene chloride extracts from the fleece are effective at stimulating ewes to ovulate (Signoret, 1991; Cohen-Tannouji et al., 1994). Cohen-Tannouji et al. (1986) found that ewes with surgically ablated olfactory bulbs

"Present address: Universidade dos Açores, 9701-851 Angra do Heroismo, Portugal.

Received 17 March 2000 displayed similar LH responses to rams as intact control ewes, thus demonstrating the role of behavioural stimuli.

There is considerable evidence that pheromone synthesis is dependent on the action of androgens. Various studies have demonstrated that both ewes and castrated males, neither of which can induce ovulation in anoestrous ewes, can induce ovulation after treatment with high doses of testosterone (Fulkerson et al., 1981; Signoret et al., 1982). In addition, testosterone also influences sexual behaviour (D'Occio and Brookes, 1982). Rams undergo seasonal fluctuations in endocrine activity, sexual behaviour and gametogenesis, as well as testicular mass and volume (Schanbacher and Lunstra, 1976; Ortavant et al., 1985). Generally, all these parameters are high at the end of the summer and in autumn, and low at the end of winter and in spring (Lincoln and Short, 1980). For example, in Soay rams 
FSH and LH concentrations begin to increase 2-4 weeks after a decrease in photoperiod, followed almost immediately by an increase in plasma testosterone concentrations accompanied by growth of the testes (Lincoln and Davidson, 1977). The sensitivity of rams to photoperiod is different from that of ewes in that sexual activity is usually stimulated 1.0-1.5 months earlier in rams. However, it is possible that if rams were introduced to anoestrous ewes soon after the summer solstice both pheromone synthesis and sexual behaviour of the rams might be insufficient to stimulate ovulation in the ewes. Treatment of rams with melatonin between mid-spring and the end of spring, at which time the animals had been exposed to several months of increasing daylength, anticipated the seasonal increase in LH secretion and testis size (Webster et al., 1991). Therefore, it is hypothesized that if melatonin treatment precipitates the seasonal peak of sexual activity in rams, then the maximum ability of rams to stimulate a physiological responses in anoestrous ewes will also be achieved earlier.

The aims of the present study were to determine whether treating rams with melatonin enhanced their ability to stimulate ovulation in seasonally anoestrous ewes. In an attempt to distinguish between the effects of pheromonal and behavioural stimulation, rams were also stimulated to show enhanced sexual activity towards anoestrous ewes by pre-exposure to ewes induced hormonally to show oestrous behaviour. Rosa and Bryant (1998) demonstrated that this is an effective measure to increase sexual behaviour of rams.

\section{Materials and Methods}

\section{Animals}

Northcountry Mule (Bluefaced Leicester female $\times$ Swaledale male) ewes $(n=225)$ were weighed and selected for the experiment on 12 June 1997. All the ewes were adults that had given birth between 17 February and 24 March and had been weaned at the beginning of June. Live body weight (mean $\pm \mathrm{SD}$ ) was $76.7 \pm 9.2 \mathrm{~kg}$ and mean $\pm \mathrm{SD}$ body condition score was $2.9 \pm 1.03$ (0: extremely emaciated; 5: excessively fat; Russel et al., 1969). The experiment also included one extra group of ewes $(n=16)$, that were used to tease the rams after being induced artificially to undergo oestrus. Rams (Texel $(n=8)$ and Charollais $(n=8))$ were also used. The rams were adult, intact and sexually experienced. Live body weight and body condition scores were $88.6 \pm$ 19.9 and $3.1 \pm 0.47 \mathrm{~kg}$, respectively. The mean $\pm \mathrm{SD}$ scrotal circumference, measured on 27 May, was $33.7 \pm 1.65 \mathrm{~cm}$.

Before and during the experimental period, both rams and ewes were kept under conditions of natural daylength and temperature (latitude $51^{\circ} 27^{\prime}$ North).

\section{Treatments}

In addition to the parameters reported above, the rams were also assessed for sexual activity by means of a libido performance test 1 month before the first introduction to experimental ewes. In this test, single rams were placed with two restrained non-oestrous ewes in a small pen for $10 \mathrm{~min}$ and an observer recorded the following features: time taken for the ram to approach the ewes; incidence of anogenital sniffs; flehmen posture; lateral approaches; licks; vocalizations; mounts and services; total time spent by the rams in courtship; reaction time (lag time between introduction of the ram and first ejaculation); and latency period (mean time between successive matings). The rams were grouped by breed and sexual activity, whereas the ewes were grouped by body weight and body condition score. The rams and ewes were allocated randomly from groups to one of the following treatments: (i) ewes $(n=25)$ remained in complete isolation from the rams until the end of the experiment (control); (ii) two rams were introduced to experimental ewes $(n=25)$ (treatment 2); (iii) two rams were introduced to experimental ewes $(n=25)$ after 2 days of close contact with four oestrous ewes (treatment 3); (iv) Two rams that had been treated with melatonin for 6 weeks were introduced to experimental ewes $(n=25)$ (treatment 4); and (v) two rams that had been treated with melatonin for 6 weeks were introduced to experimental ewes $(n=25)$ after 2 days of close contact with four oestrous ewes (treatment 5).

Treatments 2-5 were replicated. The rams, always different, were introduced to the experimental ewes on consecutive days following the sequence of treatment 2 to treatment 5 . No interval was allowed between replicates. The first two rams were introduced to the ewes on 4 July and the last two rams were introduced to the ewes on 11 July. Of the 16 rams, eight received melatonin implants and eight were not treated. Each treated ram received melatonin implants on two occasions, on 21-22 May and 20 June.

\section{Experimental procedures}

Before the experiment commenced the ewes and rams were kept isolated from the sight and smell of animals of the opposite sex for more than 3 months and this condition was maintained during the experiment for those animals not being tested. The rams were introduced to ewes in a paddock of predominantly rye grass pasture ( 0.5 hectares) where the animals were kept during the first day for the behavioural study. The next day, the animals were moved to a larger paddock (1.8 hectares) where they remained for the next 8 days. The large paddocks were separated from each other by a distance of $\geqslant 100 \mathrm{~m}$. Rams in treatments 3 and 5 had mated with oestrous ewes for $48 \mathrm{~h}$ before introduction to the experimental ewes. The oestrous ewes were induced to undergo oestrus by priming for 13 days with vaginal sponges containing $60 \mathrm{mg}$ medroxyprogesterone acetate (Veramix; Upjohn, Milton Keynes) followed by an injection (i.m.) of $500 \mathrm{iu}$ equine chorionic gonadotrophin (eCG; Intervet, Cambridge) at the time of sponge withdrawal. The sponges were removed 3 days before the rams were introduced to the experimental ewes and the rams remained with the oestrous ewes for the 2 days before introduction to experimental ewes. Melatonin was administered as an implant (s.c) (Regulin ${ }^{\circledR}$; Sanofi Animal Health, Hoechst UK Ltd, Milton Keynes) placed under a pinch of skin behind and 
near the base of the ear. The implants were positioned using an appropriate Regulin ${ }^{\circledR}$ Applicator Gun. Each implant contained $18 \mathrm{mg}$ melatonin and was developed to maintain jugular venous melatonin concentrations $>600 \mathrm{pg} \mathrm{ml}^{-1}$ for 40-70 days (Fitzgerald and Stellflug, 1991; Haresign, 1992).

\section{Data collection}

Collection of blood samples for determination of plasma melatonin concentrations. Blood samples were collected for determination of plasma melatonin concentrations on 3 June, 20 June (before receiving the implants on this day) and 1 or 2 July. One sample was taken from each ram from the contralateral vein relative to the ear of implantation between 10:00 $\mathrm{h}$ and 12:00 $\mathrm{h}$. The blood samples were collected into heparinized syringes and transferred immediately to centrifuge tubes that had been cooled on ice. After centrifugation at $4^{\circ} \mathrm{C}$ and $2000 \mathrm{~g}$ for $15 \mathrm{~min}$, the plasma was decanted and stored at $-20^{\circ} \mathrm{C}$ until assayed.

Collection of blood samples for determination of plasma testosterone concentrations. Blood samples were collected twice from all the rams for evaluation of testosterone concentrations in plasma. One sample was collected immediately before the first administration of melatonin (21-22 May) and the second sample was collected 6 weeks later (1-2 July). On each occasion, blood samples were collected for $6 \mathrm{~h}$ at $20 \mathrm{~min}$ intervals, giving a total of 19 samples. Blood (5 ml) was collected from indwelling jugular vein catheters, inserted the day before under local anaesthesia, into heparinized syringes. The subsequent blood treatment procedure, until the assay of the plasma, was the same as for melatonin. Pulses of testosterone secretion were considered to have occurred when a clear increase in concentration led up to a peak, the value of which had to exceed the $95 \%$ confidence limits of the basal concentration (mean basal concentration $\pm t \times \mathrm{SEM}$ ), followed by a continuous decrease in concentration. Exceptions were made in some cases where the last few samples were clearly indicative of a new pulse although the decrease had not yet started. The basal testosterone concentration was calculated as the mean of all samples not considered to be part of a pulse, and the amplitude of pulses was determined from the difference between concentration at the peak and at the preceding nadir (onset of the pulse).

Reproductive behaviour. Data about the sexual behaviour of rams were collected on the first day of exposure to experimental ewes in the morning for the first $3 \mathrm{~h}$ after introduction of the ram $(08: 00 \mathrm{~h}$ to $11: 00 \mathrm{~h})$ and in late afternoon for a further $3 \mathrm{~h}(17: 00 \mathrm{~h}$ to $20: 00 \mathrm{~h})$. During the first period, two video cameras (one for each ram) were used to record continuously and in detail all movements of the rams, as well as the area nearby. Filming started as soon as the rams were introduced. The images recorded on the cameras were played later on a video recorder and TV set and they were analysed in detail. During the second period of observation, direct observations were made without interruption and always by the same person who remained inobtrusive, using binoculars $(10 \times 50)$ when necessary. All occurrences of courtship behaviour, as well as the time spent by the rams courting the ewes, were noted. The courtship behaviours were those described by Banks (1964) and Lynch et al. (1992): sniffing, flehmen posture, ritualized lateral approach, mounting and mating.

The proximity between the rams and the ewes was evaluated by measuring the time spent by each ram at different distances from the ewes according to the following categories: isolated: the ram is $>10 \mathrm{~m}$ away from any of the ewes; very close: $>$ half the ewes are $<10 \mathrm{~m}$ from the ram; and close: $<$ half the ewes are $<10 \mathrm{~m}$ from the ram.

A large number was painted on the back of each ram or ewe and both flanks were marked with distinctive colours for the different treatment groups so that they could be identified from a distance.

Ovulatory response of ewes. Blood was collected from the ewes in treatments $2-5$ for determination of blood plasma concentrations of progesterone on days -4 and -1 before introduction of the ram and on days 6 and 9 after introduction of the ram. During the experimental period blood was also collected at 3 day intervals from the control ewes. Blood samples $(5 \mathrm{ml})$ were taken by jugular venepuncture and by the procedure described for melatonin. All ewes were injected i.m. with $20 \mathrm{mg}$ progesterone (Sigma Aldrich Company, St Louis, MO) in $2 \mathrm{ml}$ peanut oil (Sigma Aldrich Company) 3 days before introduction of the rams. The control ewes were injected at the same time as the ewes in treatment 2 (in both replicates). A ewe was considered to have ovulated in response to introduction of a ram when progesterone concentration profiles indicated a clear increase from values $<0.5 \mathrm{ng} \mathrm{ml}^{-1}$ in samples taken before introduction of a ram to values $>0.5 \mathrm{ng} \mathrm{ml}^{-1}$ in subsequent samples (Haresign et al., 1983). Ovulation was considered to have occurred in control ewes when progesterone concentrations were $>0.5 \mathrm{ng} \mathrm{ml}^{-1}$ in at least two consecutive samples.

\section{Hormone assay procedures}

Melatonin concentrations in ram plasma were measured by a single specific antibody, non-extracted radioimmunoassay (RIA) described by Fraser et al. (1983) with minor modifications, and validated for ovine plasma. The antiserum (G/S/704-6483-AB/S/011; Stockgrand Ltd, University of Surrey, Guildford) was raised in sheep against $N$-acetylmethoxytryptophan conjugated through the side chain to bovine thyroglobulin. It was used at a final dilution of 1:4000 in assay buffer. Tritiated melatonin was used ([O-methyl$\left.{ }^{3} \mathrm{H}\right]$ melatonin; Amersham International, Little Chalfont). The antibody-bound melatonin was separated from the free melatonin fraction with dextran-coated charcoal. The crossreactivity of the melatonin antiserum with other substances was $<0.06 \%$ except for $N$-acetyltryptamine, 6-hydroxymelatonin and $\mathrm{N}$-acetyltryptophan, with which the crossreactivity was $0.91,0.33$ and $0.22 \%$, respectively. The concentrations of the melatonin standard required to inhibit the binding of the $\left[\mathrm{O}-\right.$ methyl $\left.-{ }^{3} \mathrm{H}\right]$ melatonin to the antiserum 
G/S/704-648 -AB/S/011 by 20,50 and $80 \%$ were $20.9 \pm 2.0$, $77.8 \pm 9.0$ and $327 \pm 49.1 \mathrm{pg} \mathrm{ml}^{-1}$, respectively (mean $\pm \mathrm{SEM}$; $n=5)$. The mean intra-assay coefficient of variation calculated from one pooled control sample $\left(241.7 \pm 7.6 \mathrm{pg} \mathrm{ml}^{-1}\right)$ was $13.6 \%$ and the interassay coefficient of variation was $14.7 \%$.

The testosterone concentrations in ovine plasma were determined using a single antibody, non-extraction RIA described by Rosa et al. (2000). The amounts of testosterone standard required to inhibit the binding of the radioactive labelled testosterone to the antiserum by 20,50 and $80 \%$ were $12.9 \pm 1.30,63.0 \pm 5.50$ and $327.3 \pm 21.22 \mathrm{pg}$ per tube, respectively. The mean intra-assay coefficient of variation calculated from one pooled control sample $(6.13 \pm$ $0.23 \mathrm{ng} \mathrm{ml}^{-1}$ ) at the beginning and end of the assays was $11.0 \%$. The inter-assay coefficient of variation was $16.0 \%$.

Plasma progesterone concentration was determined using the direct addition enzyme-linked immunoassay (ELISA) described by Sauer et al. (1986), with some modifications for use with ovine plasma. The progesterone antiserum used (S1509/16; Groves et al., 1990) was raised in sheep against progesterone 11-hemisuccinate-BSA and was diluted to 1:4000 in $0.17 \mathrm{mmol}$ sodium acetate buffer $\mathrm{l}^{-1}$ ( $\mathrm{pH}$ 5.0). Groves et al. (1990) reported the crossreactivity of the antiserum with other steroids. The detection limit of the assay was $0.2 \mathrm{ng} \mathrm{ml}^{-1}$. The intra-assay coefficient of variation was $17.9 \%$ and the inter-assay coefficient of variation was $21.2 \%$.

\section{Statistical analysis}

The effect of the three dates of blood collection on mean melatonin concentration was tested by ANOVA repeated measures including treatments as the between subjects factor and date of blood collection as within subjects factor. The effects of the two dates of blood collection on mean and basal testosterone concentrations and amplitude of testosterone pulses within each group of rams were tested by pairedsample $t$ test. Differences in those parameters between the two groups of rams on each date of blood collection were tested by Student's $t$ test. The testosterone pulse frequency data were arranged in contingency tables and analysed by Fisher's exact probability test. Owing to the lack of normality, data of behaviour were square root transformed before analysis but the results are presented in the original form for clarity. When data contained many zeros, the formula square root $(0.5+x)$ where $x$ represents the original data, was applied (Zar, 1996). The effects of treatments on sexual behaviour components were analysed by ANOVA. When ANOVA detected significant differences within treatments, Fisher's post-hoc protected least-squares difference (PLSD) test was applied so that multiple comparisons could be performed. The effects of treatments on proximity between rams and ewes were evaluated by ANOVA and Fisher's PLSD test, performed separately for each category of proximity. Differences in the proportion of ewes ovulating were tested by chi-squared analysis. In the cases of $2 \times 2$ contingency tables, Yates's correction for continuity was applied.
Table 1. Plasma melatonin concentrations in control and melatonin-treated rams on 3 June, 20 June and 1-2 July

\begin{tabular}{lccc}
\hline \multirow{2}{*}{ Group } & \multicolumn{3}{c}{ Plasma melatonin concentration $\left(\mathrm{pg} \mathrm{m}{ }^{-1}\right)$} \\
\cline { 2 - 4 } Control $(n=8)$ & $10.5 \pm 2.0^{\mathrm{a}}$ & $11.4 \pm 2.1^{\mathrm{a}}$ & $18.3 \pm 2.4^{\mathrm{b}}$ \\
Melatonin-treated $(n=8)$ & $119.4 \pm 21.7^{\mathrm{b}}$ & $165.9 \pm 81.0^{\mathrm{b}}$ & $649.7 \pm 281.4^{\mathrm{c}}$ \\
\hline
\end{tabular}

Data are mean \pm SEM.

Blood samples were collected between 10:00 h and 12:00 h on each day.

Melatonin-treated rams received subcutaneous melatonin implants (Regulin ${ }^{\circledR}$ ) on 22 May and 20 June (after blood sampling).

${ }^{a b c}$ Means within rows and columns with different superscripts are significantly different $(P<0.05$ and $P<0.001$ within rows and columns, respectively).

Table 2. Plasma testosterone concentrations in control and melatonin-treated rams on 21-22 May and 1-2 July

\begin{tabular}{lcc}
\hline & \multicolumn{2}{c}{ Plasma testosterone concentrations $\left(\mathrm{ng} \mathrm{m}^{-1}\right)$} \\
\cline { 2 - 3 } Group & $21-22$ May & $1-2$ July \\
\hline Control $(n=8)$ & $2.81 \pm 0.58^{\mathrm{a}}$ & $4.28 \pm 1.88^{\mathrm{a}}$ \\
Melatonin-treated $(n=8)$ & $4.13 \pm 0.62^{\mathrm{a}}$ & $10.09 \pm 1.10^{\mathrm{b}}$ \\
\hline
\end{tabular}

Data are mean \pm SEM.

Melatonin implants (Regulin ${ }^{\circledR}$ ) were administered to each treated ram on 22 May and 20 June (after collection of blood samples).

${ }^{a b}$ Means within a row or column with different superscripts are significantly different $(P<0.01)$.

\section{Results}

\section{Effect of melatonin implants on plasma melatonin concentrations in rams}

A clear increase in plasma melatonin concentrations in rams was observed from the beginning of June to the beginning of July in both groups $(P<0.05)$ (Table 1$)$. The mean melatonin concentrations in melatonin-treated rams were significantly higher (more than ten times) than in untreated rams $(P<0.001)$. In July the melatonin concentrations (mean $\pm \mathrm{SE}$ ) were $649.7 \pm 281.4$ and $18.3 \pm 2.4 \mathrm{pg} \mathrm{ml}^{-1}$ in rams with and without melatonin implants, respectively. Melatonin concentration was never higher in a control ram than in a melatonin-treated ram.

\section{Effect of melatonin treatment on testosterone secretion in rams}

Mean plasma testosterone concentrations ranged from $0.51 \pm 0.03$ to $14.70 \pm 1.23 \mathrm{ng} \mathrm{ml}^{-1}$. There was a clear and significant $(P<0.01)$ increase $(2.5$ times $)$ in testosterone concentrations in melatonin-implanted rams between 21-22 May and 1-2 July (Table 2). In July, the testosterone concentrations in melatonin-treated rams were more than twice those of control rams $(10.09 \pm 1.10$ versus $4.28 \pm 1.88$ ng $\mathrm{ml}^{-1}$, respectively; $\left.P<0.01\right)$. Between the two sampling periods, the concentrations of testosterone increased significantly $(P<0.01)$ more (four times) in melatonin- 
Table 3. Number of testosterone pulses observed in control and melatonin-treated rams during $6 \mathrm{~h}$ on 21-22 May and 1-2 July

\begin{tabular}{|c|c|c|c|c|}
\hline \multirow[b]{3}{*}{ Group } & \multicolumn{4}{|c|}{ Number of pulses } \\
\hline & \multicolumn{2}{|c|}{ 21-22 May } & \multicolumn{2}{|c|}{ 1-2 July ${ }^{\mathrm{b}}$} \\
\hline & $0-1$ & $\geqslant 2$ & $0-1$ & $\geqslant 2$ \\
\hline Control $(n=8)$ & 6 & 2 & 4 & 4 \\
\hline Melatonin-treated $(n=8)^{\mathrm{a}}$ & 5 & 3 & 0 & 8 \\
\hline
\end{tabular}

Melatonin implants $\left(\operatorname{Regulin}^{\oplus}\right)$ were administered to each treated ram on 22 May and 20 June.

aSignificant differences between May and July values in melatonin-treated rams $(P<0.05)$.

bSignificant differences between control and melatonin-treated rams in July ( $P$ $<0.05)$.

treated rams than in control rams $(5.96 \pm 1.05$ versus $1.47 \pm 0.90 \mathrm{ng} \mathrm{ml}^{-1}$ ).

The number of testosterone pulses in individual rams during the $6 \mathrm{~h}$ period of blood collection ranged from zero to four. Pulse frequency tended to increase from May to July in both groups of rams and in July, the melatonin-treated rams tended to have more pulses per unit of time than did control rams $\left(1.63 \pm 0.46\right.$ versus $2.75 \pm 0.25$ pulses $\left.(6 h)^{-1}\right)$. The increase in number of pulses observed from May to July were only significant $(P<0.05)$ in the melatonin-treated rams and, in July, the melatonin-treated rams had significantly $(P<0.05)$ more pulses than the untreated rams (Table 3$)$. From May to July, the basal testosterone concentration in melatonin-treated rams increased significantly $(P<0.01)$ from $1.07 \pm 0.32$ to $4.21 \pm 0.74 \mathrm{ng} \mathrm{ml}^{-1}$ and the amplitude of pulses increased significantly $(P<0.05)$ from $7.60 \pm 1.21$ to $12.84 \pm 1.87 \mathrm{ng} \mathrm{ml}^{-1}$. In contrast, both of these parameters remained unaffected in control rams. In July, basal testosterone concentrations in melatonin-treated rams were significantly higher $(P<0.01)$ than those in control rams (4.21 \pm 0.74 versus $1.4 \pm 0.21 \mathrm{ng} \mathrm{ml}^{-1}$, respectively).

\section{Effect of treatments on sexual behaviour of rams}

The results of the first $3 \mathrm{~h}$ after introduction of rams to experimental ewes are shown (Fig. 1). Untreated rams tended to court the ewes to a much lesser extent than rams in any other group. Melatonin-treated rams, whether in treatment group 4 or 5, spent three times more time in sexual activity than did rams in treatment group 2 that had not received melatonin (which spent $10.1 \pm 3.9 \mathrm{~min},<5 \%$ of total time $)(P<0.05)$. Rams that had been pre-exposed to oestrous ewes (treatment 3 ) spent approximately twice as much time in sexual activity compared with rams in treatment group 2, although this difference was not significant. Rams in treatments groups 4 and 5 spent nearly the same time courting the ewes $(29.4 \pm 5.9$ and $28.6 \pm 6.9$ min, respectively) and the differences between these and rams in treatment group $3(20.3 \pm 5.2$ minutes) were not significant. Frequency of sniffing and lateral approaches also tended to be higher in rams in treatment group 3, and particularly in rams in treatment groups 4 and 5 compared with control rams, but these differences were not significant. Frequency of flehmen posture was very variable within groups and did not seem to be affected by treatment.

During the afternoon period of assessment, the sexual activity of rams decreased markedly. In general, the time dedicated by rams to court the ewes during this period did not exceed one tenth of the time dedicated to the same activity during the morning. The frequencies of sniffing, lateral approaches and flehmen posture also followed this trend. However, there was still an effect of treatment on sexual behaviour of rams. Control rams were less active than rams in other groups but significant differences in the time spent in courtship were only detected between control rams and rams in treatment groups $3(P<0.05)$ and $4(P<0.02)$, and in the frequency of sniffing between control rams and rams in treatment group $4(P<0.01)$. When data from morning and afternoon observations were pooled, the results did not deviate very much from the results found in the morning and the differences between treatments were the same as those detected in the morning.

\section{Effect of treatments on proximity between rams and ewes}

The effect of treatments on proximity between rams and ewes is shown (Fig. 2). Rams in treatment groups 4 and 5 spent significantly $(P<0.05)$ more time $(83.5 \pm 7.2$ and $88.8 \pm 19.3 \mathrm{~min}$, respectively) with ewes at distances $<10 \mathrm{~m}$ than did control rams ( $30.5 \pm 6.0 \mathrm{~min}$; very close category). However, control rams and rams in treatment group 3 spent significantly more time $(90.0 \pm 9.8$ and $66.5 \pm 8.5 \mathrm{~min}$, respectively) with ewes at a distance $>10 \mathrm{~m}$ than did rams in treatment groups $4(23.0 \pm 10.6 \mathrm{~min})$ and $5(2.8 \pm 1.6 \mathrm{~min})$ $(P<0.01)$. Treatments did not affect the time spent by animals in the close proximity category, which ranged from $59.5 \pm 7.8 \mathrm{~min}$ for control rams to $88.5 \pm 20.9 \mathrm{~min}$ for rams in treatment group 5 .

\section{Incidence of ovulation}

None of the ewes kept isolated from rams ovulated during the course of the experiment and there was no evidence that any of the other ewes ovulated before introduction of the rams. Exposure to rams significantly increased the number of ewes that ovulated (control versus all other treatments; $P<0.01$; Table 4). There was no difference in the proportion of ewes that ovulated after exposure to rams with (treatment group 2) or without (treatment group 3) recent experience with oestrous ewes. Treatment of rams with melatonin significantly increased the number of ewes that ovulated in response to introduction of a ram (treatment group 4: $P<0.05$; treatment group 5: $P<0.01$ )

\section{Discussion}

There was a significant increase in melatonin concentrations from June to July in both groups of rams, which could 

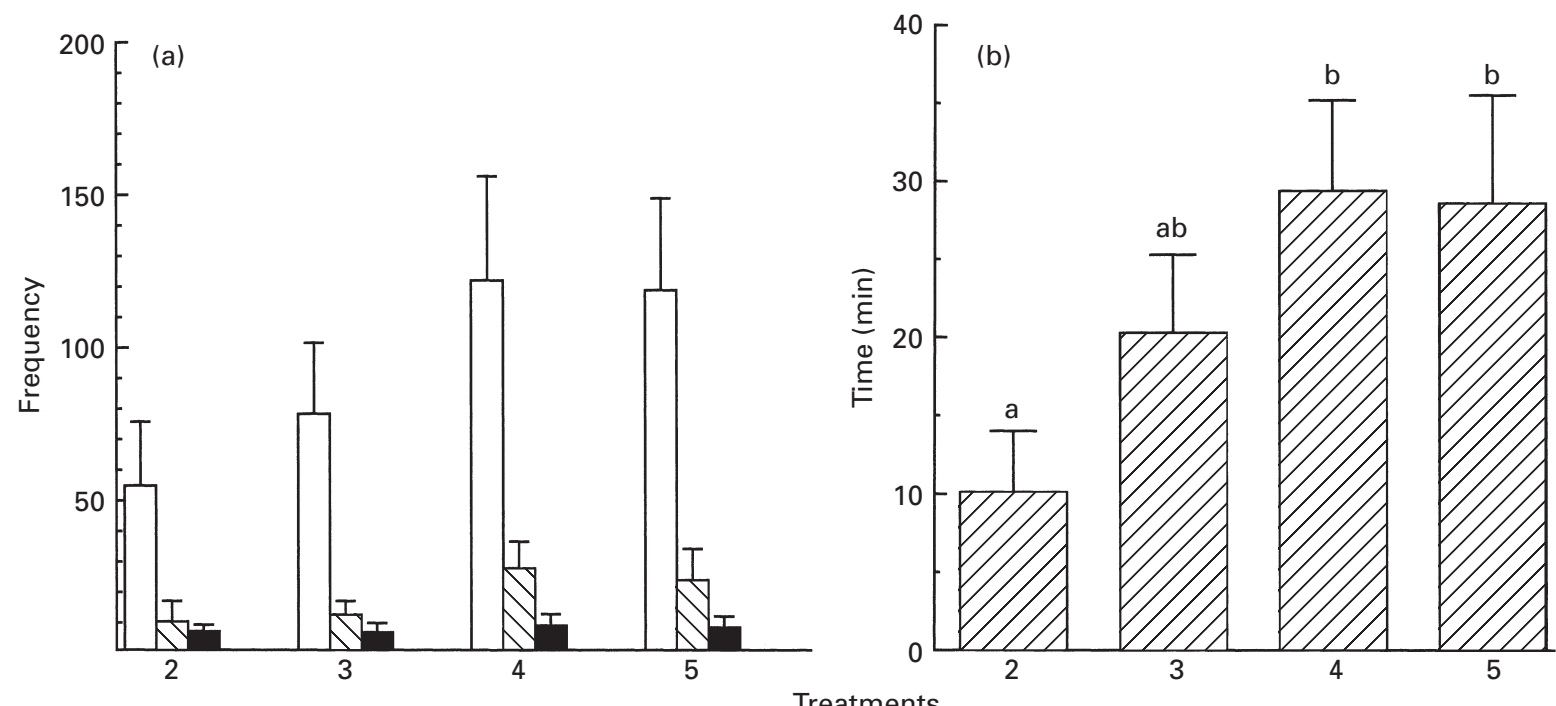

Fig. 1. The effect of sexual experience and melatonin treatment on (a) sexual behaviour components ( $\square$ : sniffing; $\square$ : lateral approaches; and $\mathbf{\square}$ : Flehmen posture) displayed by rams and (b) time spent by rams ( $\square$ ) courting seasonally anoestrous ewes during the first $3 \mathrm{~h}$ after the rams were introduced to the ewes. Treatment 2: two rams were introduced to the experimental ewes $(n=25)$; treatment 3: two rams were introduced to the experimental ewes $(n=25)$ after 2 days of close contact with four oestrous ewes; treatment 4: two rams that had been treated with melatonin for 6 weeks were introduced to experimental ewes $(n=25)$; and treatment 5: two rams that had been treated with melatonin for 6 weeks were introduced to experimental ewes $(n=25)$ after 2 days of close contact with four oestrous ewes. Values are mean $\pm \operatorname{SEM}(n=4)$. ${ }^{\mathrm{b}}$ Different letters indicate significant differences between mean values $(P<0.05)$.

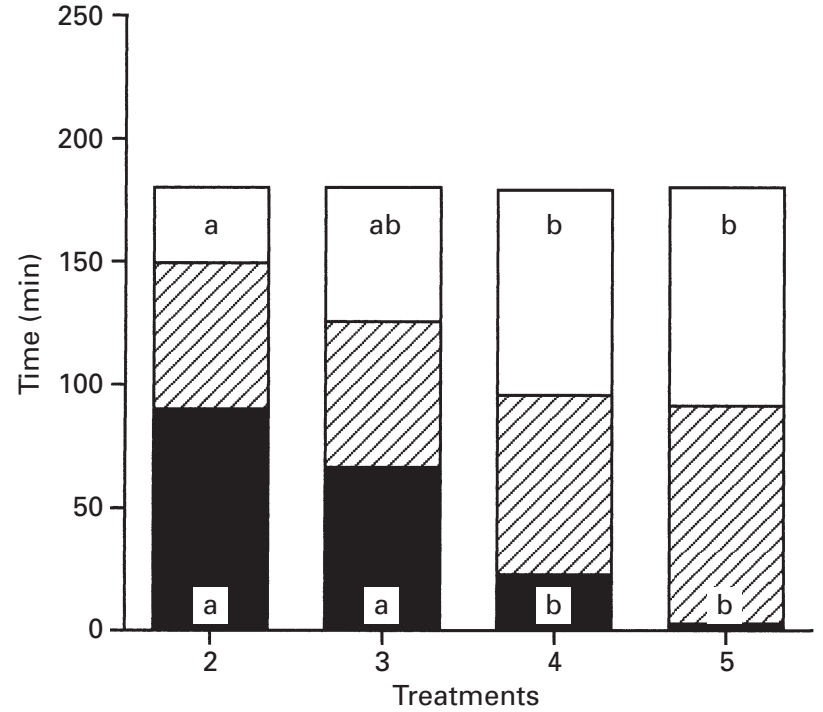

Fig. 2. The effects of sexual experience and melatonin treatment on time spent by rams in three categories of proximity to seasonally anoestrous ewes. $\mathbf{\square}$ : Isolated (ram is $>10 \mathrm{~m}$ from any of the ewes); $\square$ : close ( $<$ half the ewes are $<10 \mathrm{~m}$ from the ram); and $\square$ : very close ( $>$ half the ewes are $<10 \mathrm{~m}$ from the ram). Data are presented as mean ( $n=3$ rams). Treatment 2: two rams were introduced to the experimental ewes $(n=25)$; treatment 3: two rams were introduced to the experimental ewes $(n=25)$ after 2 days of close contact with four oestrous ewes; treatment 4: two rams that had been treated with melatonin for 6 weeks were introduced to experimental ewes $(n=$ $25)$; and treatment 5: two rams that had been treated with melatonin for 6 weeks were introduced to experimental ewes $(n=25)$ after 2 days of close contact with four oestrous ewes. ${ }^{a b}$ Different letters in the same category indicate significant differences $(P<0.05$ : 'very close' category; $P<0.01$ : 'isolated' category). indicate an effect of the photoperiod. However, this is unlikely to be the case, as seasonal fluctuations in melatonin secretion during daytime have not been reported previously. The change observed in the melatonin-treated group could be explained better in terms of an additive effect of the second melatonin implant, which the rams received on 20 June (just after blood sampling for melatonin determination at that time). The facts that after the implants, the mean melatonin concentrations of the treated group were always significantly higher than the mean of the control group and the melatonin concentrations in individual control rams never exceeded those of treated rams, demonstrate that the implants were effective in all the rams treated.

The proportion of ewes that ovulated in the various treatments indicate that there are no advantages associated with previous exposure of rams to oestrous ewes but clearly demonstrate a positive effect of the melatonin treatment. These results are in conflict with those of Knight and Gibb (1990) who reported that, despite increasing the libido of rams, implantation of Regulin ${ }^{\circledR}$ in Romney rams in Australia did not significantly increase the percentage of ewes that ovulated. However, in the study of Knight and Gibb (1990), the response in both groups was very high (> 80\%) which could have masked any beneficial effects of the melatonin treatment.

Although both previous exposure to oestrous ewes and melatonin treatment enhanced the sexual activity of the rams (although not significantly so, in the case of rams in treatment group 3), only the melatonin treatment resulted in a clear increase in plasma testosterone concentrations and in the proportion of ewes that ovulated. Considering that pheromone production may be dependent on the testosterone status of the ram (Knight, 1983; Haynes and Haresign, 
Table 4. Effect of melatonin implants and sexual experience of rams on number and percentage of ewes ovulating within 9 days of introduction of rams

\begin{tabular}{lcccc}
\hline & \multicolumn{2}{c}{$\begin{array}{c}\text { Number of ewes } \\
\text { that ovulated } \\
\text { total number of ewes) }\end{array}$} & $\begin{array}{c}\text { Total number of } \\
\text { Treatment }\end{array}$ & $\begin{array}{c}\text { Percentage of } \\
\text { ewes that ovulated } \\
\text { ewes that ovulated }\end{array}$ \\
\cline { 2 - 3 } Control & $0(24)$ & $0(24)$ & $0^{\mathrm{a}}$ & 0 \\
2 & $4(26)$ & $8(24)$ & $12^{\mathrm{b}}$ & 24 \\
3 & $5(25)$ & $7(25)$ & $12^{\mathrm{b}}$ & 24 \\
4 & $6(25)$ & $16(26)$ & $22^{\mathrm{c}}$ & 43 \\
5 & $11(25)$ & $17(25)$ & $28^{\mathrm{c}}$ & 56 \\
\hline
\end{tabular}

Control: ewes remained in complete isolation from the rams until the end of the experiment; treatment 2: two rams were introduced to the experimental ewes; treatment 3: two rams were introduced to the experimental ewes after 2 days of close contact with four oestrous ewes; treatment 4: two rams that had been treated with melatonin for 6 weeks were introduced to experimental ewes; and treatment 5: two rams that had been treated with melatonin for 6 weeks were introduced to experimental ewes after 2 days of close contact with four oestrous ewes.

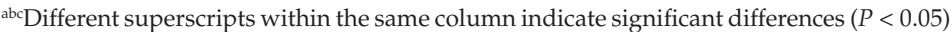

1987), these results indicate that pheromones may provide the most important stimulus for the 'ram effect', despite the proven action of behavioural cues. This finding confirms those of Rosa and Bryant (1998) that, although previous sexual experience considerably increases the expression of sexual activity directed towards anoestrous ewes, there is no convincing evidence that this results in a greater proportion of ewes that ovulate.

Neither plasma testosterone concentrations nor pulse rate showed significant increases from May to July in the control rams. However, melatonin treatment substantially increased both testosterone concentration and pulse rate, indicating sensitivity of rams to melatonin supplementation at this time. Lincoln and Ebling (1985) and Hanif and Williams (1991) determined that, for rams to respond to induced 'short days' or the alternative melatonin treatment, they need to have experienced a previous period of 'long days' (1.5-2.0 months duration) so that the refractoriness to the sexually stimulatory short photoperiods can cease. In the present study, the rams did not receive the pre-treatment of 'long days' as the implants were inserted on 22 May (5 months after the winter solstice) when they had been exposed to a naturally increasing daylength. Using a similar experimental protocol in which the rams had also received no artificial light treatment before insertion of the melatonin implant on 3 November (approximately 3.5 months after the winter solstice in the southern hemisphere) but had been exposed to a period of naturally increasing daylength, Webster et al. (1991) reported a marked increase in LH pulse frequency from week 6 after implantation. Therefore, it appears that the period of increasing daylength in spring until mid-end May provided a 'long day' priming sufficient to activate responses in the rams to exogenous melatonin at the hormonal and behavioural concentrations. From the point of view of application, this represents a great advantage as it avoids the management and costs of imposing artificial photoperiod.

In conclusion, the results of the present study demonstrate clearly that the treatment of rams with constant-release melatonin implants increases their sexual activity and ability to stimulate ovulation in seasonally anoestrous ewes. These results indicate further that a priming period of 'long days' preceding the melatonin treatment is not necessary if implantation takes place in late spring. Previous exposure of rams to oestrous ewes did not increase the proportion of anoestrous ewes that ovulated in response to introduction of rams. Further work is required to determine whether the increase in the proportion of ewes that ovulate will result in a greater proportion of ewes giving birth out of season.

The authors would like to thank P. G. Knight for providing the antibodies and for advice with the hormone assays. The authors would also like to thank members of the Department of Applied Statistics, University of Reading for advice on statistics. H. J. D. Rosa acknowledges PRAXIS XXI programme, Lisbon, for financial support.

\section{References}

Banks EM (1964) Some aspects of sexual behaviour in domestic sheep (Ovis aries) Behaviour 23 249-279

Cohen-Tannoudji J, Einhorn J and Signoret JP (1994) Ram sexual pheromone: first approach of chemical identification Physiology and Behavior 56 955-961

Cohen-Tannoudji J, Locatelli A and Signoret JP (1986) Non-pheromonal stimulation by the male of LH release in anoestrous ewe Physiology and Behaviour 36 921-924

D'Occhio MJ and Brooks DE (1982) Threshold plasma testosterone required for normal mating in male sheep Hormones and Behavior 16 383-394

Fitzgerald JA and Stellflug JN (1991) Effects of melatonin on seasonal changes in reproduction of rams Journal of Animal Science 69 264-275

Fraser S, Cowen P, Franklin M, Franey C and Arendt J (1983) Direct radioimmunoassay for melatonin in plasma Clinical Chemistry 29 396-397

Fulkerson WJ, Adams NR and Gherardi PB (1981) Ability of castrate male sheep treated with oestrogen or testosterone to induce and detect oestrus in ewes Applied Animal Ethology 7 57-66

Groves DJ, Sauer MJ, Rayment P, Foulkes JA and Morris BA (1990) The preparation of an ovine monoclonal antibody to progesterone Journal of Endocrinology 126 217-222

Hanif M and Williams HL (1991) The effect of melatonin and light treatment on reproductive performance of yearling Suffolk rams Veterinary Journal (London) 147 49-56

Haresign W (1992) Manipulation of reproduction in sheep Journal of Reproduction and Fertility Supplement 45 127-139

Haresign W, McLeod BJ and Webster GM (1983) Endocrine control of 
reproduction in the ewe. In Sheep Production pp 353-379 Ed. W. Haresign. Butterworths, London

Haynes NB and Haresign W (1987) Endocrine aspects of reproduction in the ram important to the male effect World Review of Animal Production 23 21-28

Knight TW (1983) Ram induced stimulation of ovarian and oestrous activity in anoestrous ewes - a review Proceedings of the New Zealand Society of Animal Production 43 7-11

Knight TW and Gibb M (1990) Effect of social facilitation and Regulin implants on the ram's ability to stimulate ewes Proceedings of the Australian Society of Reproductive Biology 2213

Knight TW and Lynch PR (1980) The pheromone from rams that stimulates ovulation in the ewe Proceedings of the Australian Society of Animal Production 13 74-76

Lincoln GA and Davidson W (1977) The relationship between sexual and aggressive behaviour, and pituitary and testicular activity during the seasonal sexual cycle of rams, and the influence of photoperiod Journal of Reproduction and Fertility 49 267-276

Lincoln GA and Ebling FJP (1985) Effect of constant-release implants of melatonin on seasonal cycles in reproduction, prolactin secretion and moulting in rams Journal of Reproduction and Fertility 73 241-253

Lincoln GA and Short RV (1980) Seasonal breeding: nature's contraceptive Recent Progress in Hormone Research 36 1-51

Lynch JJ, Hinch GN and Adams DB (1992) The Behaviour of Sheep: Biological Principles and Implications for Production CAB International, Wallingford

Ortavant R, Pelletier J, Ravault JP, Thimonier J and Volland-Nail P (1985) Photoperiod: main proximal and distal factor of the circannual cycle of reproduction in farm mammals Oxford Reviews of Reproductive Biology 7 306-345
Rosa HJD and Bryant MJ (1998) Effect of exposure to oestrous ewes on rams' sexual behaviour, testosterone secretion and ability to stimulate ovulation in seasonal anoestrous ewes Proceedings of the British Society of Animal Science Annual Meeting 186 (Abstract)

Rosa HJD, Juniper DT and Bryant MJ (2000) The effect of exposure to oestrous ewes on rams' sexual behaviour, plasma testosterone concentration and ability to stimulate ovulation in seasonally anoestrous ewes Applied Animal Behaviour Science 67 293-305

Russel AJF, Doney JM and Gunn RG (1969) Subjective assessment of body fat in live sheep Journal of Agricultural Science, Cambridge 72 451-454

Sauer MJ, Foulkes JA, Worsfold A and Morris BA (1986) Use of progesterone 11-glucuronide-alkaline phosphatase conjugate in a sensitive microtitreplate enzyme immunoassay of progesterone in milk and its application to pregnancy testing in dairy cattle Journal of Reproduction and Fertility 76 375-391

Schanbacher BD and Lunstra DD (1976) Seasonal changes in sexual activity and serum levels of LH and testosterone in Finnish Landrace and Suffolk rams Journal of Animal Science 43 644-650

Signoret JP (1991) Sexual pheromones in the domestic sheep: importance and limits in the regulation of reproductive physiology Journal of Steroid Biochemistry and Molecular Biology 39 639-645

Signoret JP, Fulkerson WJ and Lindsay DR (1982) Effectiveness of testosterone-treated wethers and ewes as teasers Applied Animal Ethology 9 37-45

Webster JR, Suttie JM, Veenvliet BA, Manley TR and Littlejohn RP (1991) Effect of melatonin implants on secretion of luteinizing hormone in intact and castrated rams Journal of Reproduction and Fertility 92 21-31

Zar JH (1996) Biostatistical Analysis Prentice-Hall Inc, New Jersey 